Miriam Val'ková

\title{
Recepcia konštitúcie Dei Verbum a uplatnenie jej posolstva na Slovensku
}

Sväté Písmo by malo mat' v živote veriaceho človeka vel'mi dôležité miesto ${ }^{1}$. Konciloví Otcovia v konštitúcii Dei Verbum mu venujú zvýšený záujem a dávajú ho do pozornosti aj veriacemu spoločenstvu. Pravdy predložené v prvých piatich kapitolách dosahujú vrchol v šiestej kapitole, ktorá je praktická a zaoberá sa otázkou Svätého Písma v živote Cirkvi. Je bohatá na praktické impulzy, ktoré je potrebné realizovat' aj na Slovensku v každodennej praxi aj napriek tomu, že od jej napísania a schválenia ubehlo 40 rokov. Podnety obsiahnuté v tejto kapitole sú výzvou pre spoločenstvo veriacich na Slovensku zbavit' sa presvedčenia, ktoré je pozostatkom bývalého režimu, že Sväté písmo patrí do rúk iba kňazom a teológom. Konciloví Otcovia povzbudzujú všetkých veriacich, aby radi spoznávali Božie slovo prostredníctvom čítania posvätných textov alebo posvätnej liturgie aby nadobudli „nesmierne vzácne poznanie o Ježišovi Kristovi“ (Flp 3, 8).

K uskutočneniu úloh a ciel'ov konštitúcie Dei Verbum vznikla v roku 1969 Katolícka biblická federácia, ktorá je celosvetovou inštitúciou s pobočkami v rôznych štátoch. V jednotlivých krajinách si Katolícka biblická federácia vytvára tzv. Katolícke biblické diela, ktoré šíria a napomáhajú rozvoju biblickej pastorácie a apoštolátu spôsobmi a prostriedkami, ktoré sú dostupné v danej krajine.

Slovenské Katolícke biblické dielo so sídlom vo Svite je plným členom Katolíckej biblickej federácie a orgánom Konferencie biskupov Slovenska, usiluje sa o šírenie lásky k Svätému písmu a snaží sa pochopit' jeho text podl'a najnovších vedeckých postupov². Táto inštitúcia rozvíja myšlienky konštitúcie pomocou populárno-vedeckých aktivít a projektov, ktorých ambíciou je aktualizácia Písma v živote veriaceho človeka.

Na rok 2006 má Katolícke biblické dielo definovaných osem projektov:

${ }^{1}$ Referat wygłoszony podczas międzynarodowej sesji naukowej dla uczczenia 40. rocznicy soborowej konstytucji Dei Verbum i polskiego przekładu Biblii Tysiaclecia (Kraków, 17 listopada 2005).

${ }^{2}$ Porov. A. Tyrol, Úvod do biblického štúdia, Svit 2000, s. 106-108. 


\section{Výstava Svätá zem}

2. Diaprojekcie o Svätej zemi

3. Prednášky: ako čítat' Sväté Písmo

4. Biblické publikácie

5. Biblické postavy

6. Lectio divina

7. Kurzy pre lektorov a žalmistov

8. Biblická nedel'a (každoročne 3. vel'konočná nedel'a je slávená ako biblická). Katolícke biblické dielo pripravuje materiály, ktoré sa cez diecézne obežníky dostávajú do farností. Témou štvrtého ročníka budú symboly a gestá v liturgii súvisiace so Svätým písmom.

Významným projektom je putovná výstava Svätá zem, ktorá vznikla v spolupráci s pol'skými biblistami, predovšetkým s Dr. Romanom Bogaczom z Krakowa, ktorý Katolíckemu biblickému dielu poskytol fotografie. Výstava bola otvorená v novembri 2003 a doteraz navštívila približne štyridsat' miest a pokračuje d'alej. Sprostredkúva a vizualizuje poznatky o miestach a skutočnostiach vo Svätom písme z pohl'adu geografického, dejinného a kultúrneho. Súčast'ou expozície je brožúra s topografickým a spirituálnym komentárom.

Ďalším projektom je preklad a vydávanie časopisu Sväté písmo pre každého, ktorého ciel'om je formovanie krest'anskej kultúry slovenskej verejnosti. Vydávaním tohto časopisu sme sa pripojili k európskym národom, ktoré poznajú Sväté písmo a zároveň sa zaujímajú o diela svetového umenia a literatúry vytvorené na biblické motívy. Časopis ponúka čitatel'om úplné texty spolu s komentármi, ilustráciami ${ }^{3}$ a svojou štruktúrou je prispôsobený všetkým vekovým kategóriám.

Ćinnost' Katolíckeho biblického diela je zameraná aj na publikovanie kníh s biblickou tematikou, ako aj tematicky zamerané prednášky s inštrukciami a metodickými pokynmi ako čítat' Sväté písmo. Vysvetlenie a konkrétny opis metódy meditatívneho čítania Svätého písma formou lectio divina sa vo všetkých kostoloch Slovenska uskutoční tento rok na prvú adventnú nedel'u 27. novembra 2005 prostredníctvom pastierskeho listu biskupov Slovenska. Katolícke biblické dielo vydalo brožúru s návodom, ktorá bude k dispozícii najmä mládeži.

Kreatívnym projektom sú kurzy biblických postáv, v ktorých je prepojená katechéza s praktickou činnost'ou zhotovovania malých figúr a názornou ukážkou konkrétnej biblickej témy. Ciel'om kurzu je lepšie poznávanie a pochopenie textu Svätého Písma a uplatnenie a asimilácia biblického posolstva v praxi najmä v práci s det'mi.

\footnotetext{
${ }^{3}$ Porov. G. Ravassi, Sväté Písmo pre každého, Bratislava 2003, č. 11, roč. 2, s.35.
} 
K aktivítám zameraným na mládež patria biblické krúžky, najmä ich zakladanie a príprava materiálov, v ktorých je ponúknutý rozbor najznámejších statí Svätého písma, metodické pokyny a modlitby s biblickým obsahom

Okrem spomenutých projektov a aktivít Katolícke biblické dielo spolupracuje s biblickými organizáciami iných cirkví, masmédiami (Rádio Lumen) a významnou je a j spolupráca s katolíckymi školami na projekte prípravy učebných osnov pre 4- ročné katolícke gymnáziá.

Ciel'om práce Katolíckeho biblického diela je dvíhat' biblickú kultúru a krest'anské povedomie na Slovensku a popularizovat' Sväté písmo. Je to náročná práca, ale aj pozvanie pre nás veriacich, aby sme po 40-ročnom odcudzení znovu objavili Božie Slovo, spoznali jeho účinnost' a živost' (Hebr 4, 12) v našom každodennom živote.

\section{Zoznam použitej literatúry}

Sväté Písmo Starého i Nového Zákona, Trnava 2001.

Dokumenty II Vatikánskeho koncilu: Vieroučná konštitúcia O Božom zjavení Dei Verbum.

PÁPEŽsKá Biblická Komisia, Interpretácia Biblie v Cirkvi, Spišská Kapitula 1995.

Neuer J., Ross H., Viera Cirkvi v úradných dokumentoch jej Magistéria. Trnava 1995.

Ravasi G., Sväté Písmo pre každého. Bratislava 2003, č. 11, roč. 2.

Tyrol A., Poznámky k štúdiu biblickej exegézy, Svit 1999.

Tyrol A., Úvod do biblického štúdia, Svit 2000.

http://www.kbd.sk

Ružomberok

MIRIAM VAL'KOVÁ

\section{Streszczenie}

\section{Recepcja konstytucji Dei Verbum i upowszechnienie jej orędzia na Słowacji}

Konstytucja dogmatyczna Dei Verbum spotkała się na Słowacji z pełnym i wszechstronnym przyjęciem. Od 1993 roku pracuje tu krajowa filia Katolickiej Federacji Biblijnej. W roku 2002 został przygotowany komentarz do tej konstytucji. Miały także miejsce liczne inicjatywy, jak seminaria oraz konferencje, w czasie których przybliżano społeczeństwu dokumenty soborowe oraz ich założenia teologiczne i duszpasterskie. Katolickie Dzieło Biblijne (Katolícke biblické dielo) realizuje na Słowacji konkretne projekty. W posiedzeniach członków Rady systematycznie bierze udział biskup, którego obecność jest potwierdzeniem ścisłej współpracy Dzieła Biblijnego z episkopatem. Konferencja Episkopatu Słowacji przygotowała list pasterski na 40-lecie ogłoszenia konstytucji Dei Verbum, w którym propaguje i zachęca do medytacyjnego czytania Pisma Świętego metodą lectio divina. 


\section{Nowość!}

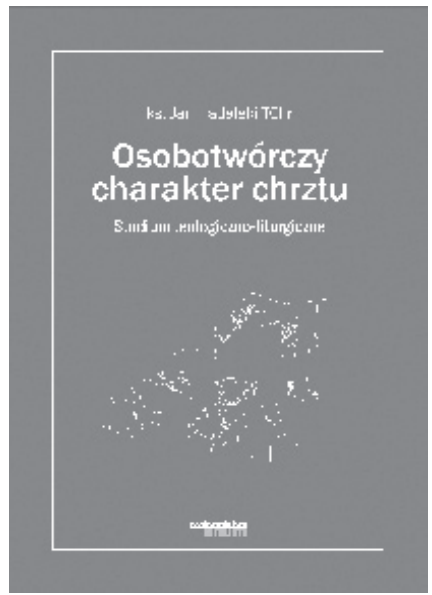

ks. Jan Hadalski TChr

\section{Osobotwórczy charakter chrztu}

Studium teologiczno-liturgiczne

290 stron $\cdot$ format $14,5 \times 20,5 \mathrm{~mm}$

oprawa broszurowa $\cdot$ cena 25 zt

Osobotwórczy charakter chrztu to oryginalna i doskonała książka dotycząca jednego z podstawowych tematów chrześcijaństwa - sakramentu chrztu świętego. Według autora chrzest nie tylko styka świat osobowy Boga ze światem ludzkim, ale także poprzez ten sakrament Bóg w szczególny, „,chrzcielny” sposób konstytuuje osobę chrześcijanina. Chrzest został przy tym ukazany bardzo realistycznie: nie jest to jedynie obrzęd, gest religijny, „rejestracja” we wspólnocie, lecz wielkie misterium, żywe i twórcze. Tworzenie osoby w sakramencie chrztu i poprzez sakrament obejmuje poziom indywidualny osoby, a także ukonstytuowanie osoby społecznej - Kościoła.

Czytelnik znajdzie w publikacji szereg sugestii tak w odniesieniu do indywidualnych kontaktów z Bogiem - Panem ludzkich wydarzeń, jak i duszpasterskich inicjatyw. Praca wpisuje się w nurt jakże drogiego Janowi Pawłowi II personalizmu. Jan Paweł II stwierdził w liście apostolskim Tertio millennio adveniente, że odnowienie świadomości chrzcielnej jako podstawy chrześcijańskiego życia należy do głównych tematów duszpasterstwa. Wiele wspólnot parafialnych czy seminaryjnych, które organizują kilka razy w ciągu roku specjalne nabożeństwa o takim charakterze, może znaleźć w książce ciekawe treści.

\section{Zamówienia}

Wydawnictwo UNUM · ul. Kanonicza 3 · 31-002 Kraków tel. (12) $4225690 \cdot$ e-mail: unum@ptt.net.pl Koszt przesyłki ponosi wydawnictwo. 